\title{
DESCRIPTION oF A NEW PELAGIC FISH FROM NEW ZEALAND.
}

\section{By J. Douglas Ogilby.}

Some months ago the Australian Museum received, through the kindness of the Fresh Food and Ice Company, Sydney, a fine specimen of an unknown pelagic fish from New Zealand, being one of a consignment forwarded to the Company for sale in Sydney, the bulk of which consisted of Trout, Rock Cod (Percis colias), and Flounders (Rhombosolea monopus). This example, having been imported for edible purposes, had of course been thoroughly cleaned before being placed in the ice chamber, and I am therefore, unable to give the number of pyloric appendages.

The occurrence of this genus in Australasian waters, is quite as interesting as the discovery of Tetragonurus* some years ago at Lord Howe Island, and bears a close analogy to it, both genera being more or less distinctly Mediterranean types.

\section{Centrolophus maoricus, $s p$. nov.}

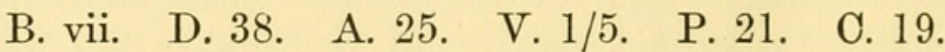

The length of the head is equal to that of the caudal fin, and five and a half in the total length; the greatest height of the body is beneath the longest dorsal rays, and is contained five times in the same. The eye is large, and is surrounded by a prominent naked lid; it is situated near the upper profile of the head, and its diameter is four and one-tenth in the length of the head, and one and one-seventh in that of the snout, which is obtuse and abruptly truncated, and projects slightly beyond the lower jaw ; the interorbital space is convex and its width is equal to the length of the snout. The nostrils are situated far forward, immediately behind the angle of the snout; the anterior is oval and vertical, the posterior much larger and subarcuate. The upper profile of the head is slightly concave. The jaws are equal, and the cleft of the mouth is of moderate width, the maxilla reaching to beneath the anterior fourth of the orbit. The vertical limb of the preopercle is straight and slightly inclined forward, its angle and lower limb finely denticulated; the margins of the sub- and inter-opercles rather more strongly so. A single series of cardiform teeth in the jaws, so irregularly placed as to form in many cases an apparently double series. The dorsal fin

* Macleay, Proc. Linn. Soc. N. S. Wales, x. p. 718, and op. cit. (2) i. p. 511; Ramsạy \& Ogilby, op. cit. (2) iii. p. 9. 
commences a little behind the posterior half of the pectoral, and the length of its base is two and one-fifth in the total length; the anterior rays are short and gradually increase in length to the twelfth which, with the thirteenth and fourteenth, is the longest in the fin, and about one-seventh longer than the snout; behind these the rays become abruptly shorter, so that the outer margin of the fin is concave behind them, and the posterior two or three rays appear to be distinctly elongated, the last being about equal to the eighteenth: the anal commences beneath the middle dorsal ray, and its shape is similar to that of the dorsal, the base of which is exactly twice the length of its base; the fifth ray is the longest, and is but a fraction shorter than the longest dorsal ray, while the distance between the base of the first ray and the origin of the caudal is contained one and one-fourth times in that between the same point and the extremity of the snout: the pectoral is small and rather pointed, the fourth to seventh rays the longest, two and one-seventh in the length of the head: ventrals small, equal in length to the snout: caudal deeply emarginate. Scales very small, each one pierced by a small, central, circular pore ; opercle, sub- and inter-opercle scaly, the scales being of equal size to those on the body ; rest of the head naked, covered with a thick and densely porous skin ; vertical fins scaly over about twothirds of their height. Lateral line forming a long curve to beneath the longest dorsal rays.

Colors.-Uniform brown, darkest above; the sides of the head washed with dull blue; the fins and opercles with gold.

Type.-In the Australian Museum.

The Australian Museum also possesses a specimen of Pteraclis velifer, a species previously unrecorded from New Zealand.

\section{REVIEW OF THE GENUS SCHEDOPHILUS, COCCO, AND ITS ALLIES.}

\section{By J. Douglas Ogilby.}

The present paper was suggested by the occurrence on the coast of New South Wales of a specimen of Schedophilus maculatus, this being the first record for the genus from Australian waters, and the time has been deemed opportune to review the history, such as it is, of the various species, the more especially that these pelagic forms are liable to occur at any time upon any part of the 


\section{$2 \mathrm{BHL}$ Biodiversity Heritage Library}

Ogilby, J. Douglas. 1893. "Description of a new pelagic fish from New Zealand." Records of the Australian Museum 2, 64-65. https://doi.org/10.3853/j.0067-1975.2.1893.1195.

View This Item Online: https://www.biodiversitylibrary.org/item/31634 DOI: https://doi.org/10.3853/j.0067-1975.2.1893.1195

Permalink: https://www.biodiversitylibrary.org/partpdf/4617

\section{Holding Institution}

Harvard University, Museum of Comparative Zoology, Ernst Mayr Library

\section{Sponsored by}

Harvard University, Museum of Comparative Zoology, Ernst Mayr Library

\section{Copyright \& Reuse}

Copyright Status: NOT_IN_COPYRIGHT

This document was created from content at the Biodiversity Heritage Library, the world's largest open access digital library for biodiversity literature and archives. Visit BHL at https://www.biodiversitylibrary.org. 